\title{
Forms of Communication in Local Wisdom-Based Environmental Education at Eco Camp
}

\author{
Santi Susanti, Sukaesih, Iwan Koswara \\ Fakultas Ilmu Komunikasi \\ Universitas Padjadjaran \\ Jatinangor, Indonesia \\ santisusanti2202@gemail.com
}

\begin{abstract}
Eco Learning Camp or Eco Camp is a non-profit organization established to develop educational, conservation, research and other creative activities based on the environment. It's located near Djuanda Forest Park, Dago Pakar. Eco Camp has the vision to produce quality human beings who care about the environment. The educational activities run by Eco Camp are based on the concept of mulasara bumi, guguru ka bumi, caring the earth and learn from the earth, a concept based on Sundanese local wisdom to stay close to nature. This study aims to reveal the forms of communication used at Eco Camp in instilling awareness to preserve the environment based on Sundanese local wisdom. This research uses a qualitative descriptive method, in the form of observation and in-depth interview with Eco Camp personnel and the use of documents that support the research. The results showed group communication is the most commonly used form of communication in instilling awareness of maintaining the environment, both small group and large group communication. Other forms are instructional communication and media communication, both online and offline media. This study concludes that environmental awareness can emerge through patterned education with appropriate communication and conducive environment. The use of local wisdom concept that is close to nature contributes in strengthening the cultivation of consciousness to maintain good relations with nature.
\end{abstract}

Keywords-group communication; mediated communication; Sundanese local wisdom; environmental education; environmental care

\section{INTRODUCTION}

The life pattern of human has led changes in many things, including climate change due to global warming. We can feel that climate has significantly changed. For example, the air felt today is hotter than ever so that the ice in the north pole has already been melting [1], many farmlands are cracked due to drought, seasonal changes cannot be predicted certainty, as well as various other changes that occur in This world. If left untreated, the global warming conditions will continue for the foreseeable future.

Various ways are being done to reduce the impact of ongoing climate change, one of which is to instill the awareness that the current world climate condition is critical and needs a helping hand from people who care about the efforts to instill the awareness that pioneered by some people who care about the environment by setting up Eco Learning Camp or Eco Camp, located in Dago Pakar Barat No. 3,
Bandung regency. Eco Camp was built as a home for environmental studies, which offers an environment-based value model of education. As an educational home, the teaching given is aimed at building awareness of the environment [2]. Various ways are used to communicate messages related to the environment in order to raise awareness to keep the earth so as not to be severely damaged by human activities. This study aims to reveal the forms of communication that takes place in the process of environmental-based values education at Eco Camp.

\section{RESEARCH METHOD}

This research uses qualitative descriptive. Qualitative research is a research used to examine natural objects by placing researchers as a key instrument. [3] It called descriptive because this research does not use hypotheses and variables but only describes and analyzes existing events without special treatment of the objects under study. According to Rakhmat, descriptive research is simply describing a situation or event, not seeking or explaining relationships, not testing hypotheses or making predictions. "[4] The data analysis is inductive, and the results of qualitative research emphasize the meaning of generalization.

This research was conducted to reveal the forms of communication used in environmental-based values education conducted at Eco Camp in order to instill environmental awareness, and to express the meaning of environmental education activities conducted at Eco Camp.

The subject of this research is Eco Camp as environmental value-based education provider, which aims to build awareness of the importance of keeping the earth to get a better life and friendlier with the environment. The object is the communication that takes place in environmental education activity at Eco Camp.

Research data obtained through interviews, observations, and literature review related to the research. The interview was conducted to Eco Camp manager to know the background and purpose of establishing Eco Camp to do environmental education activity. Observation is done in a participatory way to know and feel the atmosphere and situation when education at Eco Camp. The literature review is done through reviews of articles or articles and photos and videos related to environmental education at Eco Camp. 


\section{RESULTS AND DISCUSSION}

\section{A. Overview of Eco Camp}

Eco Learning Camp or Eco Camp is a development of Spirit Camp founded in 2002 by Yayasan Sahabat Lingkungan Hidup. The foundation established by concern for children and their future. Initially, Spirit Camp is located in Ledeng, Bandung. Spirit Camp provides a number of activities and facilities for children and teenagers, so they can play outdoors. Spirit Camp activity had moved to Kota Baru Parahyangan before finally in 2012 located in Forest Park Ir. H. Djuanda, Dago, Bandung. Evolved into Eco Learning Camp or Eco Camp under Yayasan Sahabat Lingkungan Hidup, the organization was established to develop educational, conservation, research, and community development activities as well as other creative activities based on the environment.

Eco Camp is currently located at Jalan Dago Pakar Barat 3 Bandung, near Tahura Djuanda, occupying approximately 5400 square meters of land. On the land, Eco Learning Camp (ELC) or Eco Camp is used as a means to hold various meetings and training in education and environment. Eco Camp is also built by following the criteria of Green Building Council Indonesia.

In running its activities, Eco Camp has a vision to produce qualified human beings who care for earth and learn from earth. The concept of caring earth and learn from earth, which in Sundanese is mulasara bumi, the earth is a concept based on the local wisdom of the Sundanese people to always be close to nature and make nature as an integral part of the life of the Sundanese. In practice, human life is not to conquer nature, but to adapt to nature.

The mission to build younger generation who have better environment awareness and improve the quality of life through education, conservation, research, and community empowerment, Eco Camp invites people to love and care the universe to arise the desire to nurture and learn from nature. In managing Eco Camp, Yayasan Sahabat Lingkungan Hidup accompanied with Balai Pengaan Taman Raya Djuanda Forestry Office of West Java Government and Parahyangan Catholic University.

Values education at Eco Learning Camp is an informal education delivered through environmental and natural discourse that is integrated with knowledge about science and related culture so as to raise awareness of the importance of environment and nature so that the realization of active participation to preserve the environment and nature. The basic values embedded in environmental education at Eco Learning Camp consist of integrity, sharing spirit, responsibility and reward. These values are described as follows:

\section{B. Cultivation of Ecological Values}

The cultivation of ecological values at Eco Learning Camp is done through 7 new awareness of ecological life, which consists of quality life pattern, simple, efficient, caring, sharing spirit, meaningful and hopeful.
- QUALITY: willing to learn to be responsible and not depend entirely on others. Learn simple things to do such as washing dishes, installing bed linen, cleaning rooms, and so on.

- SIMPLE: learn to be simple in lifestyle with no exaggeration in eating, shopping and ownership, as well as mindset. For example, calming the mind when faced with problems, to find a solution.

- EFFICIENT: applying a frugal lifestyle by utilizing resources as necessary and not excessive. Using solar electricity for lighting, save on water use by drinking from their respective bottles so there is no need to wash glasses over and over and spend water.

- CARE: cultivate concerns ranging from concern for yourself, others, and the environment. Conducted behavior is not smoking.

- SHARE: learn to share in the limitations. Not just the material, also the ability of science and so on.

- MEANINGFUL: Find meaningfulness with simple things, such as being happy with others. When sharing we will find ourselves meaningful and happy.

- HOPEFUL: to be a bearer of hope by doing good in each environment.

Application of the seven new awareness of ecological living is carried out through a simple and ecological lifestyle.

- BBM (Bring a Drinking Bottle) to reduce glass laundry, get used to drinking water and bring a drinking bottle.

- Minimizing plastic and packaging to reduce waste that produces toxins

- $100 \%$ non-smoking. If anyone smokes, they are charged Rp 500,000 for air cleansing compensation

- Life Skill, learn simple things to support daily life, tidy up room, wash dishes, put up bed linen, clean room, help cook, and others

- Simple lifestyle; take food with attention to other friends, no leftover food, simple and healthy food, drink healthy water.

- Life-saving patterns; using electrical energy wisely and economically because it is limited, its source of solar energy. Use enough water.

- There is a moment of silence at 12:00 and 15:00, where all activities must be stopped and we learn to listen to the sound of nature.

\section{The forms of communication used}

\section{1) Traditional game}

Traditional games used in in Eco Camp as a way to instill moral values related to the environment. According to Ferry Sutrisna Wijaya, Eco Camp manager, the idea to include traditional games in cultivating the moral values of goodness and environmental value, because the game is from the nature 
so it can be returned to nature to instill good values. Ferry feels, the values in the game still remain relevant to apply in today's conditions. Using traditional games, the cultivation of moral values does not feel forced, because the process is not directly delivered, but through the meaning of the moral values of the game in the form of reflection delivered after the game is done.

Ferry believes if children often play traditional then can live the values in it and carry out those values in everyday life, will be realized a better society, more peaceful, harmless, reconciled with fellow human beings, reconciled with universe, life is more comfortable.

\section{2) Group Communications}

At Eco Camp, environmental education materials presented in groups, either large groups or small groups. Giving material in groups is done order of efficiency and effectiveness of delivery. Because in practice, there are materials that must be given together, for example in traditional games or games that train the cohesiveness of the participants.

\section{3) Instructional Communication}

According to Pawit M. Yusup [5], the instructional term is derived from the word instruction, meaning instruction, lesson, or even command or instruction. Instructional communication basically has a purpose to understand the target (communicant) in terms of behavior change to a better direction in the future. Behavioral changes are mainly concerned with aspects of cognition, affection, and psychomotoric.

Based on the findings, the instructional communication that took place at Eco Camp was held at a time of silence at the appointed time, delivered through loudspeakers. Also instructional communication is done through the eco camp website, as well as sheets containing instructions in some sections at Eco Camp.

\section{CONCLUSION}

The values and environment education given patternedly by an agency concerned with the environment is believed contribute to the emergence of awareness to maintain a good relationship with the natural environment. The children and adolescents period is a good time to receive an understanding of awareness about the importance of loving the environment and preserving nature so as to give positive feedback to human beings. The right pattern made the awareness process well received by the participants at Eco Camp.

Communication has an important role in delivery the material of environmental value-based educational to the public. In this study, some of the communications used in conveying materials are traditional games, group communication and instructional communication.

\section{REFERENCES}

[1] Lapisan es di Kutub Utara mencair, kapal tanker bisa melintas. http://www.bbc.com/indonesia/majalah-41046299. accessed 14 March 2018

[2] Climate Reality Leaders Voices from Indonesia (24 Hours of Reality 2016).
[3] https://www.youtube.com/watch?time_continue $=130 \& v=s v z B d$ FYdPZM. accessed 14 March 2018

[4] Sugiyono, Metode Penelitian Kuantitatif \& Kualitatif RND, Bandung: Alfabeta, 2007.

[5] J. Rakhmat, Metode Penelitian Komunikasi, Bandung: PT Remaja Rosdakarya, 2002.

[6] P.M. Yusup, Komunikasi Instruksional: Teori dan Praktik, Jakarta: Bumi Aksara, 2010. 